\title{
A case of giant panda ovarian cancer diagnosis and histopathology
}

\author{
Qi Gao ${ }^{1 \dagger}$, Chengdong Wang ${ }^{2 \dagger}$, Desheng $\mathrm{Li}^{2^{*}}$, Hemin Zhang ${ }^{2}$, Linhua Deng ${ }^{2}$, Caiwu Li ${ }^{2}$ and Zhengli Chen ${ }^{*^{*}}$ (D)
}

\begin{abstract}
Background: Ovarian cancer is diagnosed clinically by detecting ovarian cancer-related factors and markers. Here, we report a case of giant panda ovarian tumor metastasis with a combination of clinical and histopathological diagnosis.

Case presentation: Histopathological studies revealed severe lesions and tumor cells in the ovaries, lungs, spleen, kidneys and perianal tissue. Immunohistochemistry staining showed that the ovarian cancer markers B7-H4, CA125, and HE4 were highly expressed in the lungs, kidneys, spleen, ovaries and perianal tissue. Tumor marker tests detected significantly high levels of AFP in serum.

Conclusion: Clinical biomarkers combined with histopathology can provide a more accurate diagnosis of ovarian cancer metastasis and identification of ovarian cancer types than either method alone. The giant panda's death may be due to granulosa cell tumor and theca cell tumor metastasis causing multiple organ dysfunction or even failure.
\end{abstract}

Keywords: Giant panda, Ovarian cancer, Histopathology, Diagnostics

\section{Background}

Ovarian cancer is the fifth most common cause of cancer death in women behind lung cancer, breast cancer, colorectal cancer, and pancreatic cancer [1]. There are two major types of ovarian cancer: epithelial and germ cell neoplasms. About $90 \%$ of ovarian cancers are epithelial and develop on the surface of the ovary. These tumors are often bulky and involve both ovaries. Germ cell tumors are derived from the eggs within the ovary and, if malignant, tend to be highly aggressive [2].

The CA125 antigen is a high molecular weight glycoprotein that is expressed in most epithelial ovarian cancers. It is currently the favored tumor marker for epithelial ovarian cancer and has played an important role in diagnosis and incorporating the risk of a malignancy index. However, the sensitivity and specificity of CA125 is poor, and CA125 is also a valid marker for many diseases other than ovarian cancer [3].

\footnotetext{
*Correspondence: 1050133153@qq.com; chzhli75@163.com

${ }^{\dagger} \mathrm{Qi}$ Gao and Chengdong Wang contributed equally to this work.

${ }^{2}$ China Giant Panda Conservation Research Center, Dujiangyan, China

${ }^{1}$ Laboratory of Animal Disease Model, College of Veterinary Medicine,

Sichuan Agricultural University, Chengdu, China
}

Human epididymis protein 4 (HE4) is a glycoprotein that is highly expressed in ovarian cancer. It is mainly expressed in the reproductive system and in respiratory and salivary gland secretions [4]. It has been proposed as a potential biomarker for ovarian cancer because the combination of HE4 and CA125 was more accurate than any other markers in predicting malignant ovarian tumors [5]. The Food and Drug Administration (FDA) in U.S. has approved HE4 for monitoring the recurrence of disease in ovarian cancer patients [6]. B7-H4, a newly identified member of the B7 family, is involved in the negative regulation of $\mathrm{T}$ cell-mediated immunity in peripheral tissues. Research has found that B7-H4 inhibits apoptosis and promotes tumor cell growth, adhesion, and invasion into immunodeficient systems [7]. B7-H4 is overexpressed in ovarian cancer tissues and elevated levels are detected in the serum of ovarian cancer patients, but not in patients with benign diseases [8]. So B7-H4 may play a more important role in tumorigenesis and metastasis. Ovarian cancer is generally diagnosed clinically by detecting ovarian cancer-related factors and markers, but the biomarker analysis alone is not sensitive enough, because the expression of related biomarker in serum can not directly reflect the extent of lesions in

(c) The Author(s). 2018 Open Access This article is distributed under the terms of the Creative Commons Attribution 4.0 International License (http://creativecommons.org/licenses/by/4.0/), which permits unrestricted use, distribution, and 
the tissue. So here, we report a case of giant panda ovarian tumor metastasis by combination of clinical and histopathological diagnosis. It allows us to visually understand the pathological changes in the tissue and to further diagnose the disease by detecting biomarkers.

\section{Material and methods}

\section{Histopathology}

The body of the giant panda was systematically dissected. Specimens from the heart, lungs, liver, spleen, kidneys, perianal tissue, and ovaries were fixed in $4 \%$ paraformaldehyde phosphate buffer and embedded in paraffin using routine protocols. Paraffin-embedded materials were sectioned at $5 \mu \mathrm{m}$ for staining with $\mathrm{H} \& \mathrm{E}$ (hematoxylin-eosin).

\section{Immunohistochemistry}

Sections were dewaxed in xylene and dehydrated in alcohol and antigen retrieval was achieved by microwaving them in citrate solution for $15 \mathrm{~min}$. They were then soaked in $0.3 \%$ hydrogen peroxide for 20 min to block endogenous peroxidase activity. Sections were blocked by $5 \%$ bovine serum albumin and incubated with the primary antibody against CA125 (Boiss, China), HE4 (Boiss, China) and B7-H4 (Boiss, China) at $4{ }^{\circ} \mathrm{C}$ overnight. After rinsing, a rabbit IgG SABC (StreptAvidin-Biotin Complex) immunohistochemical staining kit (Boster, China) was used according to the manufacturer's protocols. Tissue sections were visualized with the substrate $D A B$ (diaminobenzidine) chromogen (Boster, China). Positive results were dark blue particles, located in the cytoplasm or nucleus.

\section{Case presentation}

The giant panda was a female who was rescued in the wild in Shaanxi Province, China in 1988. The pedigree number is 418 . She started to reduce her activity, walking slowly, and her activity did not increase during estrus since March 9, 2015. On April 7, she was found to walk more slowly. Her hindlimbs were unable to support her as she walked, and the main manifestations were ankylosis, lying or standing eating, and the inability to curl up or sit on April 11. We suspected that her waist was injured and conducted a systemic examination after anesthesia on April 27, 2015, including basic physiological indicators tests, routine blood tests, blood biochemical tests, a DR (Digital Radiography) test, and a B-scan ultrasound test. The results showed that the number of white blood cells and AST / ALT ratio was elevated (Tables 1 and 2), suggesting that there was inflammation in her body. Furthermore, the lateral longitudinal ligament and anterior longitudinal ligament of the 10th thoracic vertebra and the third lumbar showed band calcification with the formation of a bridge of the
Table 1 The results of routine blood examination

\begin{tabular}{lll}
\hline Projects & Value & Unit \\
\hline WBC & 15.61 & $10 \mathrm{E} 9 / \mathrm{L}$ \\
Neu\% & 86.9 & $\%$ \\
Lym\% & 6.1 & $\%$ \\
Mon\% & 2.6 & $\%$ \\
Eos\% & 4.3 & $\%$ \\
Bas\% & 0.10 & $\%$ \\
Neu\# & 13.56 & $10 \mathrm{E} 9 / \mathrm{L}$ \\
Lym\# & 0.95 & $10 \mathrm{E} 9 / \mathrm{L}$ \\
Mon\# & 0.41 & $10 \mathrm{E} 9 / \mathrm{L}$ \\
EoS\# & 0.67 & $10 \mathrm{E} 9 / \mathrm{L}$ \\
Bas\# & 0.02 & $10 \mathrm{E} 9 / \mathrm{L}$ \\
RBC & 7.15 & $10 \mathrm{E} 12 / \mathrm{L}$ \\
HGB & 131 & $\mathrm{~g} / \mathrm{L}$ \\
HCT & 36.50 & $\%$ \\
MCV & 51.1 & $\mathrm{fL}$ \\
MCH & 18.3 & $\mathrm{pg}$ \\
MCHC & 359 & $\mathrm{~g} / \mathrm{L}$ \\
RDW-CV & 14.4 & $\%$ \\
RDW-SD & 32.3 & $\mathrm{fL}$ \\
PLT & 1470.0 & $10 \mathrm{E} 9 / \mathrm{L}$ \\
MPV & 6.6 & $\mathrm{fL}$ \\
PDW & 15.3 & $\%$ \\
PCT & 0.970 & \\
\hline
\end{tabular}

Table 2 The results of blood biochemical examination

\begin{tabular}{lll}
\hline Projects & Value & $\mathrm{Unit}$ \\
\hline TBIL & 6.7 & $\mu \mathrm{mol} / \mathrm{L}$ \\
TP & 62.0 & $\mathrm{~g} / \mathrm{L}$ \\
ALB & 21.5 & $\mathrm{~g} / \mathrm{L}$ \\
AST & 101.0 & $\mathrm{U} / \mathrm{L}$ \\
ALT & 25.4 & $\mathrm{U} / \mathrm{L}$ \\
ST/LT & 3.98 & $/$ \\
PA & 57.4 & $\mathrm{mg} / \mathrm{L}$ \\
CHE & 546 & $\mathrm{U} / \mathrm{L}$ \\
TBA & 22.20 & $\mu \mathrm{mol} / \mathrm{L}$ \\
Cr & 71.5 & $\mu \mathrm{mol} / \mathrm{L}$ \\
UA & 144.0 & $\mu \mathrm{mol} / \mathrm{L}$ \\
TG & 5.68 & $\mathrm{mmol} / \mathrm{L}$ \\
CHOL & 6.70 & $\mathrm{mmol} / \mathrm{L}$ \\
HDL & 2.13 & $\mathrm{mmol} / \mathrm{L}$ \\
LDL & 3.26 & $\mathrm{mmol} / \mathrm{L}$ \\
APOA1 & 0.25 & $\mathrm{~g} / \mathrm{L}$ \\
APOB & 0.09 & $\mathrm{~g} / \mathrm{L}$ \\
GLU & 2.36 & $\mathrm{mmol} / \mathrm{L}$ \\
\hline & &
\end{tabular}



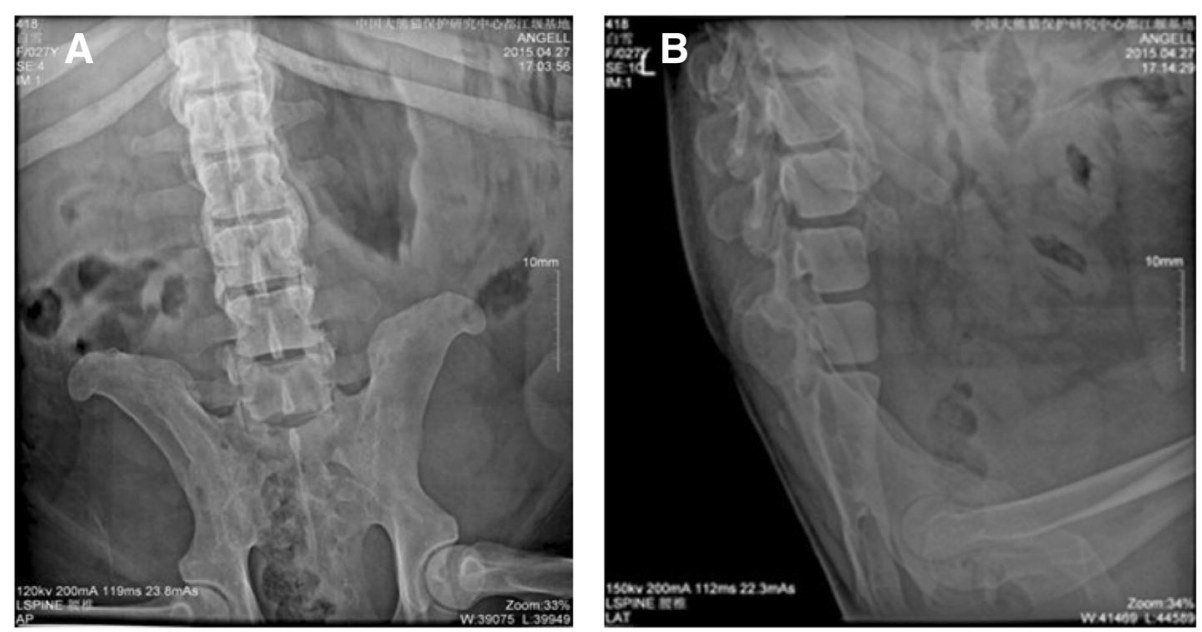

Fig. 1 The results of Digital Radiography diagnosis. The lateral longitudinal ligament and anterior longitudinal ligament of the lumbar occurred band calcification with the formation of a bridge of the bone. a Lumbar anteroposterior position. $\mathbf{b}$ Lumbar lateral position

bone (Fig. 1). A $1.46 \times 1.18 \mathrm{~cm}$ cyst was found in the left kidney by B-scan ultrasound (Fig. 2). After taking Cefalexin $2 \mathrm{~g} /$ times and special nursing (daily massage for waist, hot compress) for 7 consecutive days, the patient's condition further deteriorated and she was lying sideways in the house with almost no ambulation. Hematological tumor marker tests revealed a significant increase in AFP (alpha-fetoprotein) values (Table 3). Eventually she died at 18:00 on June 12, 2015.

The corpse weighed $85 \mathrm{~kg}$ and had more than a dozen neoplasms in the perianal area (Fig. 3a). Anatomical examination found a large number of ovarian neoplasms, the largest at $7 \mathrm{~cm}$ in diameter (Fig. 3b). The liver was hard in texture and had fat accumulation on the surface (Fig. 3c). The lungs were also hard and inelastic. There

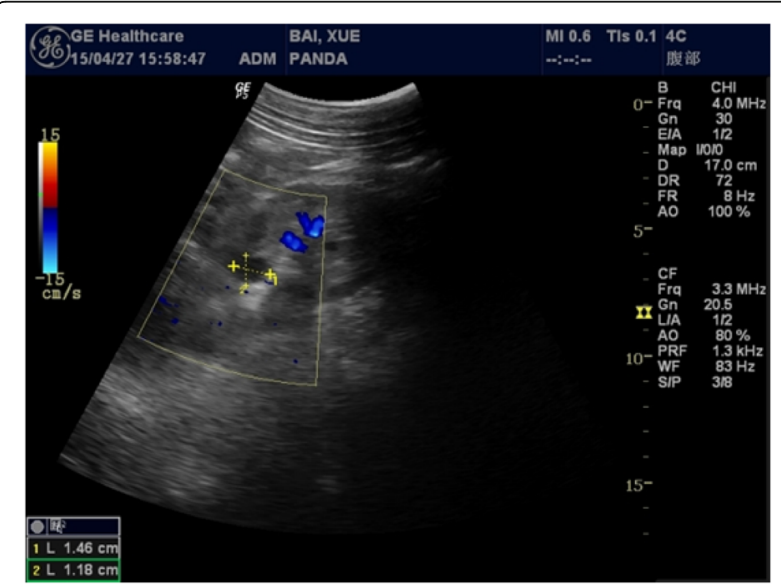

Fig. 2 The results of B-scan ultrasound. We found a $1.46 \times 1.18 \mathrm{~cm}$ cyst in the left kidney. Blue indicates blood flow away from the probe were visible ptosis in the left upper part of the gums (Fig. 3d) and a total of about $5000 \mathrm{ml}$ in ascites.

Histological examination showed severe alveolar atrophy or even disappearance, pulmonary fibrosis hyperplasia in the lungs, and visible tumor cell metastasis (Fig. 4a-c). Ovarian tissue showed a large number of round cells were nests or cord-like proliferation, spindle-shaped cells proliferation in its periphery, accompanied by the formation of collagen fibers, tumor cell atypia is not obvious, rare cells split phase, and local necrotic calcification area (Fig. 4d-f). Perianal tissue showed tumor cell metastasis accompanied by fibrogenesis (Fig. 4g-h). There were fewer spleen lymphocytes than in normal, and a proliferation of monocytes (Fig. 4i). In the liver we saw severe hepatic steatosis, partial necrosis, multifocal calcification, and small focal inflammatory infiltration (Fig. 4j). In the kidneys we saw partial of glomerular atrophy, mild glomerular swelling, tubular significant dilatation, visible proteinuria, and cell tubes (Fig. 4k). In the heart we saw severe swelling of myocardial cells and granular degeneration with partial necrosis in the heart (Fig. 4l).

Immunohistochemical staining showed that the ovarian cancer markers B7-H4, CA125, and HE4 were highly

Table 3 The test results of tumor markers in serum

\begin{tabular}{lll}
\hline Projects & Value & Unit \\
\hline AFP & 70.4 & $\mathrm{ng} / \mathrm{ml}$ \\
CA125 & 10.00 & $\mathrm{U} / \mathrm{ml}$ \\
CA15-3 & 1.20 & $\mathrm{U} / \mathrm{ml}$ \\
CA19-9 & 10.50 & $\mathrm{U} / \mathrm{ml}$ \\
CEA & 5.00 & $\mathrm{ng} / \mathrm{ml}$ \\
\hline
\end{tabular}



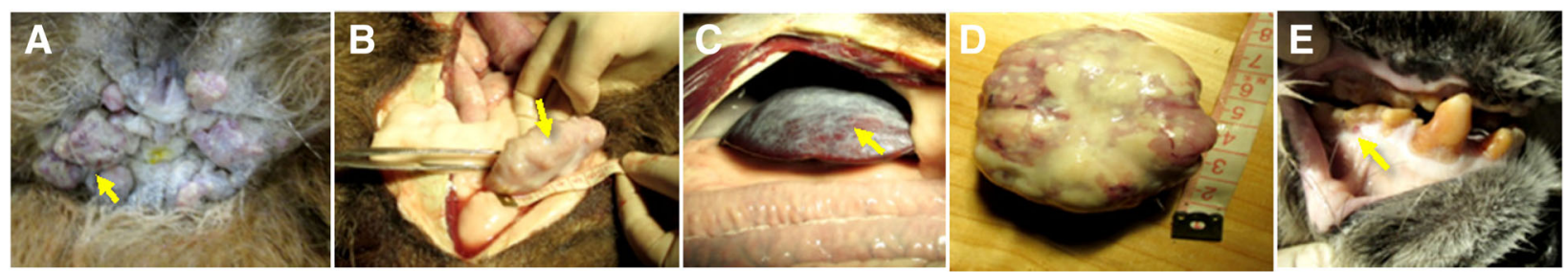

Fig. 3 Anatomical pathology of the main organ lesions. a Many neoplasms in the perianal area. b Ovarian tumor. c A large number of ovarian neoplasm. $\mathbf{d}$ Hard texture of the liver, fat accumulation on the surface. e Visible ptosis in the left upper part of the gums

expressed in the lungs, kidneys, spleen, ovaries and perianal tissue (Fig. 5).

\section{Discussion and conclusions}

Blood tests showed inflammation in the body of the giant panda, and we treated her with anti-inflammatory treatment. The giant panda was found with ligament calcification and formation of bone bridge by DR examination. Combined with her daily performance, we diagnosed her as senile with degenerative spondylitis [9]. There is still a lack of treatment for this disease in current medical research; we could only minimize her pain with methods like massage.

Severe lesions in multiple organs were observed by histopathology. Moreover, the visible ovarian granulosa cells and theca cells become cancerous in the ovary and even transferred to the lungs, kidneys, perianal tissue and spleen. This may have severely affected the functioning of these organs. We also detected high expression of B7-HE, CA125, and HE4 by immunohistochemistry in the lungs, ovaries, kidneys, perianal tissues, and spleen. The metastasis of ovarian tumors to these areas was confirmed by the detection of ovarian cancer biomarkers in these tissues [10]. CA125 and overexpressed AFP were also detected in serum. AFP is a tumor antigen that is expressed in cells during embryonic development and is abundantly expressed in adult tumor cells. It is useful in the clinical detection of tumor markers [11]. There is research showing that malignant ovarian tumors include germ cells and sex cord stromal

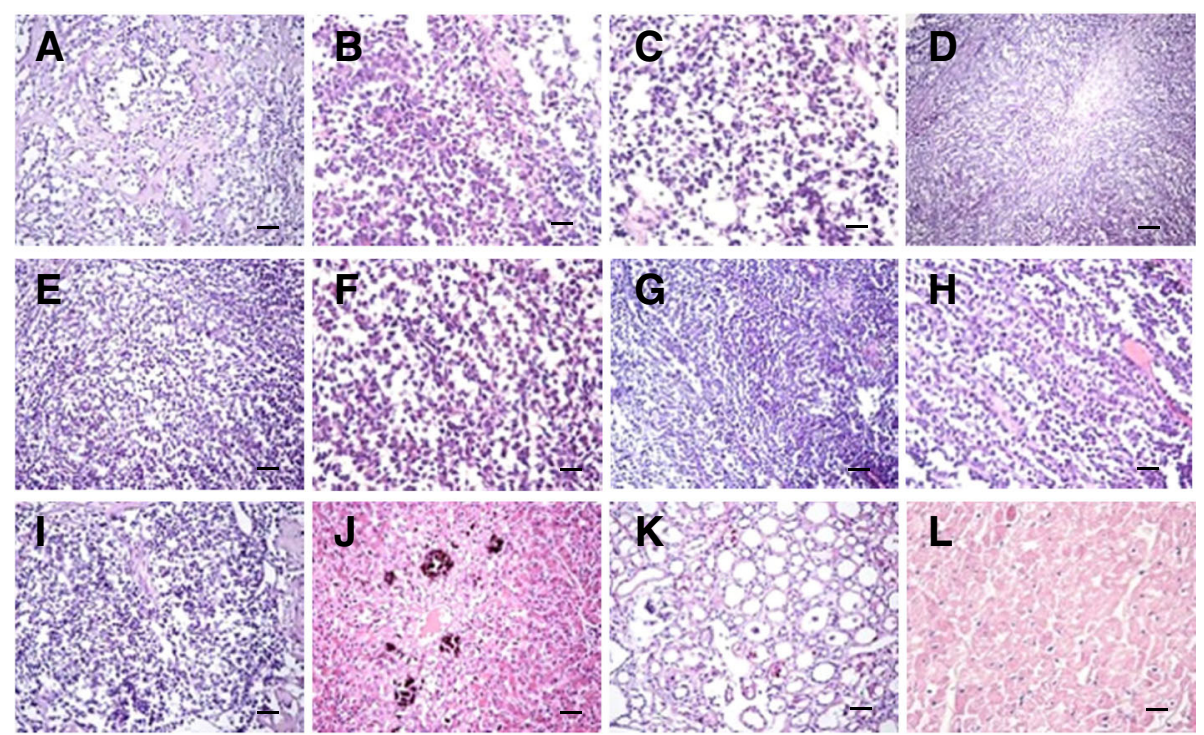

Fig. 4 Histopathological results of main lesion. a-c Severe alveolar atrophy or even disappearance, pulmonary fibrosis hyperplasia in the lung, visible tumor cell metastasis. $\mathbf{d}$-f Ovarian tissue showed a large number of round cells were nests or cord-like proliferation, spindle-shaped cells proliferation in the periphery, accompanied by the formation of collagen fibers, tumor cell atypia is not obvious, rare cells split phase, local necrotic calcification area. $\mathbf{g}$-h Perianal tissue showed tumor cell metastasis accompanied by fibrogenesis. i Fewer spleen lymphocytes than normal, monocyte proliferation. j Severe hepatic steatosis, partial necrosis, multifocal calcification, small focal inflammatory infiltration of the liver. $\mathbf{k}$ Part of glomerular atrophy, mild glomerular swelling, tubular significant dilatation, visible proteinuria and cell tube in the kidney. I Severe swelling of myocardial cells, granular degeneration with partial necrosis in the heart. (d: Bar $=100 \mu \mathrm{m} . \mathbf{a}, \mathbf{e}, \mathbf{g}, \mathbf{i}, \mathbf{j}$ and $\mathbf{k}: \operatorname{Bar}=50 \mu \mathrm{m} . \mathbf{b}, \mathbf{c}, \mathbf{f}, \mathbf{h}$ and $\mathbf{I}: \operatorname{Bar}=20 \mu \mathrm{m})$ 

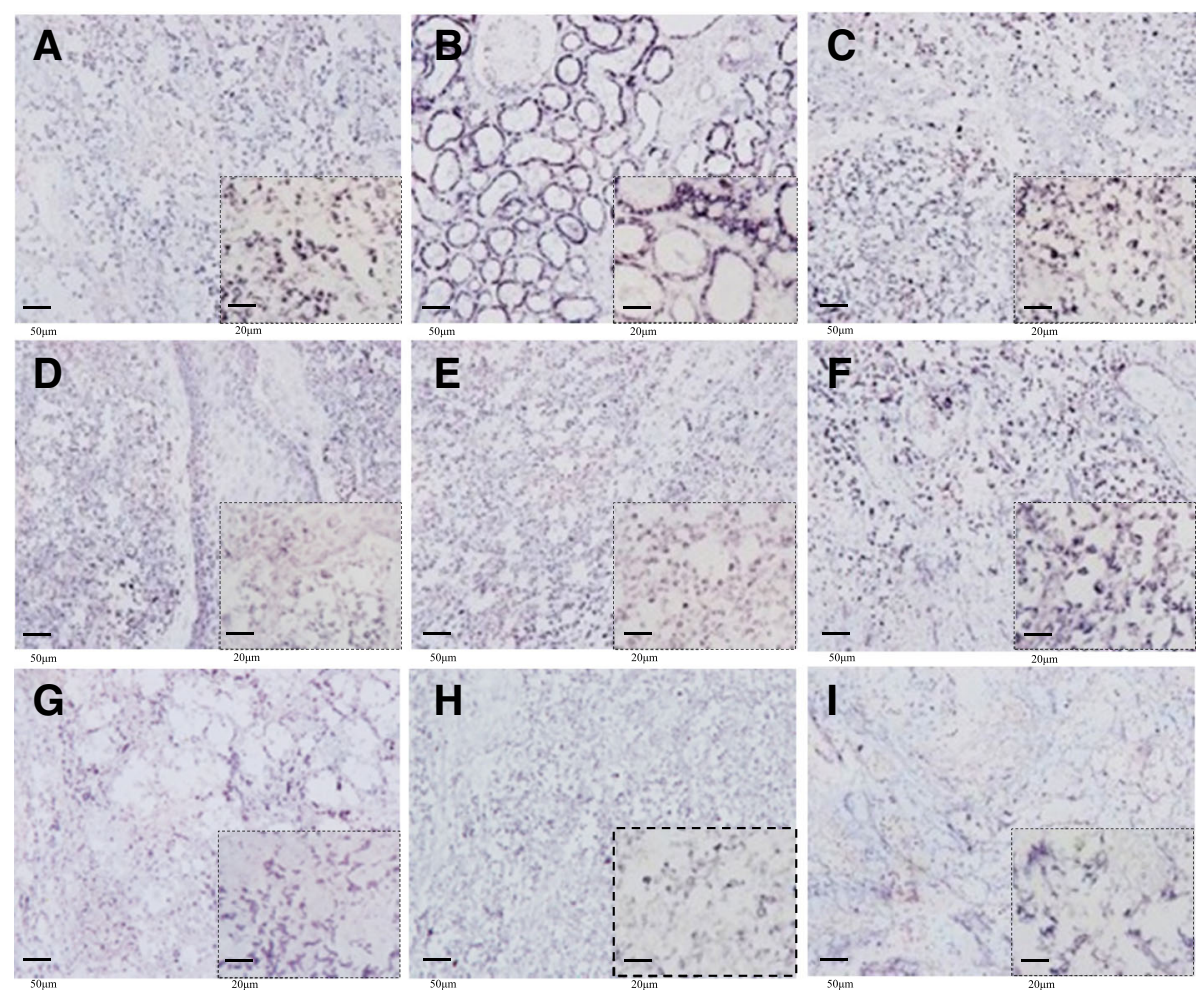

Fig. 5 Immunohistochemistry for B7-H4, CA125 and HE4. a-c B7-H4 is abundantly expressed in the cell membranes of the lungs, kidneys, and spleen. d-f CA125 is abundantly expressed in the cell membranes and cancer cells of perianal tissue, ovaries, and lungs. g-i HE4 is highly expressed in cancer cells of the lungs, ovaries, and spleen

tumors, which are associated with marked elevation serum of AFP $[12,13]$.

Ovarian granulosa cell tumors (GCTs) are uncommon neoplasms that arise from the sex-cord stromal cells of the ovary [14]. It has been reported that metastasis of ovarian granulosa tumor to the lung leads to structural changes and dysfunction in the lung tissue [15]. This giant panda is diagnosed with ovarian cancer [16]; her death may be due to granulosa cell tumor and theca cell tumor metastasis leading to multiple organs dysfunction or even failure. In summary, clinical biomarkers combined with histopathology can provide a more accurate diagnosis of ovarian cancer metastasis and identification of ovarian cancer types. In clinical examination, in addition to detecting biomarkers of ovarian cancer in serum, it is possible to perform histopathological examination by biopsy.

\section{Acknowledgements}

We wish to thank Dr. Chengdong Wang, Dr. Desheng Li, Dr. Hemin Zhang, Dr. linhua Deng, Dr. Caiwu Li and Dr. Zhengli Chen for their technical assistance.
National Key Scientific Instrument and Equipment Development Project of China (2013YQ49085906)

\section{Availability of data and materials \\ Not applicable.}

\section{Authors' contributions}

$\mathrm{QG}, \mathrm{ZC}$ and $\mathrm{CW}$ conceived and designed the study. QG, DL, HZ, LD and $\mathrm{CL}$ performed the experiments. QG and CW wrote the paper. ZC revised it critically for important intellectual content the manuscript. ZC gave final approval of the version to be published. All authors read and approved the manuscript.

\section{Ethics approval}

All protocols were approved by the animal care and use committee of Sichuan agricultural university, following the guidelines on animal experiments which come under the permit No.DY- S20174411.

\section{Consent for publication}

Not applicable.

\section{Competing interests}

The authors declare that they have no competing interests.

\section{Publisher's Note}

Springer Nature remains neutral with regard to jurisdictional claims in published maps and institutional affiliations.
Funding
National Key R\&D Project of China (2017YFD0501706).

National Key Technology Research and Development Program of the Ministry of Science and Technology of China (2014BAI03B01). 
Received: 31 May 2018 Accepted: 25 September 2018

Published online: 12 October 2018

\section{References}

1. Roett MA, Evans P. Ovarian cancer: an overview. Am Fam Physician. 2009; 80(6):609.

2. Berria M. Cervical, ovarian, and uterine cancers. Salem Press; 2013. http:// search.ebscohost.com/login.aspx?direct=true\&db=ers\&AN=86193973\&lang= zh-cn\&site=eds-live.

3. Moss EL, Hollingworth J, Reynolds TM. The role of CA125 in clinical practice. J Clin Pathol. 2005;58(3):308-12

4. Jr NB, Krasznai ZT, Balla H, Csobán M, Antal-Szalmás P, Hernádi Z, Kappelmayer J. Elevated human epididymis protein 4 concentrations in chronic kidney disease. Ann Clin Biochem. 2012;49(Pt 4):377.

5. Andersen MR, Goff BA, Lowe KA, Scholler N, Bergan L, Drescher CW, Paley P, Urban N. Use of a symptom index, CA125, and HE4 to predict ovarian cancer. Gynecol Oncol. 2010;116(3):378-83.

6. Zhao T, Hu W. CA125 and HE4: measurement tools for ovarian Cancer. Gynecol Obstet Investig. 2016;81(5):430-5.

7. Cheng L, Jiang J, Gao R, Wei S, Nan F, Li S, Kong B. B7-H4 expression promotes tumorigenesis in ovarian cancer. Int J Gynecol Cancer. 2009;19(9):1481-6.

8. Simon I, Zhuo S, Corral L, Diamandis EP, Sarno MJ, Wolfert RL, Kim NW. B7 h4 is a novel membrane-bound protein and a candidate serum and tissue biomarker for ovarian cancer. Cancer Res. 2006;66(3):1570-5.

9. Resnick D, Niwayama G, Goergen TG. Comparison of radiographic abnormalities of the sacroiliac joint in degenerative disease and ankylosing spondylitis. AJR Am J Roentgenol. 1977;128(2):189-96.

10. Hamd-Ghadareh S, Salimi A, Fathi F, Bahrami S. An amplified comparative fluorescence resonance energy transfer immunosensing of CA125 tumor marker and ovarian cancer cells using green and economic carbon dots for bio-applications in labeling, imaging and sensing. Biosens Bioelectron. 2017:96:308

11. Wang XW, Xu B. Stimulation of tumor-cell growth by alpha-fetoprotein. Int J Cancer. 1998;75(4):596

12. Shaikh NA, Memon F, Samo RP. TUMOR MARKERS; efficacy of CA-125, CEA AFP, \& Beta HCG an institutional based descriptive \& prospective study in diagnosis of ovarian malignancy. Prof Med J. 2014;21(4):621-7.

13. Mani R, Jamil K. Specificity of serum tumor markers (CA125, CEA, AFP, Beta HCG) in ovarian malignancies. Trends Med Res. 1981:2(3):128-34.

14. Pectasides D, Pectasides E, Psyrri A. Granulosa cell tumor of the ovary. Cancer Treat Rev. 2008;34(1):1-12.

15. Shimizu K, Yamada T, Ueda Y, Yamaguchi T, Masawa N, Hasegawa T. Cytologic features of ovarian granulosa cell tumor metastatic to the lung. Acta Cytol. 1999;43(6):1137-41.

16. Farghaly SA. Advances in diagnosis and Management of Ovarian Cancer. New York: Springer; 2014

Ready to submit your research? Choose BMC and benefit from:

- fast, convenient online submission

- thorough peer review by experienced researchers in your field

- rapid publication on acceptance

- support for research data, including large and complex data types

- gold Open Access which fosters wider collaboration and increased citations

- maximum visibility for your research: over $100 \mathrm{M}$ website views per year

At $\mathrm{BMC}$, research is always in progress.

Learn more biomedcentral.com/submissions 